Review

\title{
Long-Term Sustainability from the Perspective of Cullet Recycling in the Container Glass Industry: Evidence from Italy
}

\author{
Mario Testa ${ }^{1}$ (D), Ornella Malandrino ${ }^{1}$, Maria Rosaria Sessa ${ }^{1, *}$, Stefania Supino ${ }^{2}$ and \\ Daniela Sica ${ }^{1}$ \\ 1 Department of Business Sciences-Management and Innovation Systems (DISA-MIS), University of Salerno, \\ 84084 Salerno, Italy; mtesta@unisa.it (M.T.); ornellam@unisa.it (O.M.); dsica@unisa.it (D.S.) \\ 2 Department of Human Science and Promotion of the Quality of Life, San Raffaele University, \\ 00166 Rome, Italy; ssupino@unisa.it \\ * Correspondence: masessa@unisa.it; Tel.: +39-89-963-042
}

Received: 24 July 2017; Accepted: 24 September 2017; Published: 1 October 2017

\begin{abstract}
Glass manufacturing is a high-volume process, during which large substance quantities are transformed into commercial products, and significant amounts of non-renewable resources and energy (i.e., thermal fuels and electrical power) are consumed. The main purpose of this study is to give a critical explanation of the performance of the Italian container glass industry from the perspective of cullet being recycled, to outline the opportunities for transition towards circular business models that stimulate innovation in new sectors based on reverse-cycle activities for recycling. In 2015, disparate performances have been achieved as regards the container glass recycling rate in northern, central, and southern Italy, accounting for around $73 \%, 64 \%$, and $55 \%$, respectively. In fact, only northern Italy is in line with European targets, as by 2025 it will only need to increase its current performance by two percentage points, unlike central and southern Italy that will have to increase performance by, respectively, $11 \%$ and $20 \%$. This shows a need to improve the efficiency of municipal waste collection systems in central and southern Italy, where undifferentiated waste still holds appreciable amounts of glass. Consequently, we propose several improvement channels, from the revision of waste legislation to the re-engineering of waste management supply chains.
\end{abstract}

Keywords: container glass industry; cullet recycling; circular economy; Italy; solid waste management

\section{Introduction}

Glass is an amorphous solid without a crystalline internal structure that is mainly produced from natural raw materials abundant in the earth's crust. During the manufacturing process, elements from the raw materials form a new random network that is linked together by oxygen bridges. Thousands of diverse chemical compositions can be made into glass, and their different formulas affect the mechanical, electrical, chemical, optical, and thermal properties of the finished product [1]. Even if glass manufacturing depends mainly on the finished product, processes have a common origin: the melting of required resources.

The most important glass type is soda-lime, which consists mainly of silicon dioxide $(71-75 \%)$, sodium oxide (12-16\%), and calcium oxide (10-15\%) [2]. The mixture of ingredients melted together at high temperatures $\left(1500-1600{ }^{\circ} \mathrm{C}\right)$ forms glass having a structure similar to a liquid, but which behaves like a solid at ambient temperature, and hence, glass can be poured, blown, pressed, and moulded into a wide array of shapes. Therefore, the glass industry serves sectors covering different products, applications, and markets. 
Today, glass is one of the most important materials, playing a key role both in sectors considered traditional (building, automotive, packaging) and in more innovative ones. In the innovative sectors, glass in combination with specific substances is used for high-tech applications, such as space exploration, medical research, optics, and telecommunications. Worldwide, the main glass sectors are as follows: container glass, the largest world glass sector, which includes a large variety of products utilized in packaging foods, beverages, cosmetics, pharmaceuticals, etc.; flat glass, the second largest, which includes products utilized in building, transport, and photovoltaic energy; continuous filament glass and glass wool for insulation, roofing, the reinforcement of composite materials, etc.; domestic and special glass, which includes, respectively, drinking glasses and oven dishes and optical glass, electrical equipment screens, and lighting glass.

The glass industry is essentially a commodity industry, in which over $80 \%$ of output is sold to other industries, although ways of adding value to high-volume products have been developed to ensure the industry remains competitive [3] (p. 2).

Glass manufacturing is a high-volume process, during which large quantities of substances are turned into commercial products, consuming large amounts of non-renewable resources and energy in the process (thermal fuels and electrical power) [2,4,5]. Therefore, it is an energy- and resource-intensive industry, and, like other similar industries, such as the iron and steel, aluminium, cement, pulp and paper, and chemicals industries, is central to supporting the transition towards higher levels of energy and material efficiency, low carbon emissions, and increased resource productivity, through the deployment of better performance towards sustainability [6]. Enterprises in energy- and material-intensive industrial sectors are central to reducing energy consumption in several ways, including technological improvements in manufacturing processes to reduce energy waste and recover lost energy and recycling secondary raw materials originating from industrial and municipal waste. Particularly, in glass manufacturing, cullet (crushed glass ready to be recycled) is used as a batch material, substituting for virgin raw materials. Cullet is classified as internal or external if it derives, respectively, from imperfect products rejected at quality control during the industrial process of glass manufacturing and production cut-offs or from waste glass collected and/or reprocessed for recycling. It enhances the glass melting process's efficiency and reduces the amount of air pollutants (dust, other particulate matter, greenhouse gas (GHG) emissions, etc.) [3] (p. 98). This leads to decreasing costs, an improving material and energy efficiency, and the minimization of pollution [7].

The European glass industry, the world's largest producer with a share of around one third of the total glass market [8], has been engaged for decades to reach higher levels of energy and material efficiency and minimize environmental impact, thus increasing resource productivity; enhancing the recyclability of glass products through a life-cycle perspective; improving the economic, environmental, and social performance of sustainability [9]; and identifying new avenues in the field of the circular economy. A successful implementation strategy based on the circular economy requires a combined view of three main aspects: resource scarcity, waste generation, and sustaining economic benefits [10]. This is achieved with the joint support of all stakeholders.

The glass industry applies the principles of the circular economy more effectively. Unfortunately, for the European glass industry, the final amount of energy consumption is not available for each member state, because data on the quantities and types of energy sources used are considered sensitive and are not made public by manufacturers. As such, the main purpose of this work is to focus on and evaluate the performance of the Italian container glass industry from the perspective of cullet recycling, outlining the opportunities for a transition towards circular business models that stimulate innovation in new sectors dedicated to reverse-cycle recycling activities.

This paper first analyses the state-of-the-art in the European glass industry, paying attention to the container glass sector to evaluate potential challenges in energy and material efficiency improvements, with a focus on environmental sustainability and industrial competitiveness. The Italian container glass industry, one of the most important European manufacturers of container glass, is then investigated to outline its characteristics and evaluate its performance in raw material and energy efficiency as well 
as emissions reduction. Such aspects are addressed in the light of recent European regulations for waste prevention programmes, with a stronger emphasis on recovery operations, including recycling according to the Waste Framework Directive 2008/98 [11] and the End-of-Waste criteria. These criteria specify when certain waste, including glass cullet [12,13], ceases to be waste and obtains the status of a product or secondary raw material [12]. This emphasizes a new vision to realize a transition towards a circular economy [14].

Regarding this point, the main contribution of this paper is to highlight the challenges that Italy has to face to achieve the new glass recycling targets of $75 \%$ by 2025 and $85 \%$ by 2030 . All this in spite of the fact that Italian glass packaging industry has long since paved the way for other energy-intensive industries, adopting circular modes of operations.

The paper is structured as follows. Section 2 provides a brief historical overview and a landscape of the European glass industry in the past decade to better identify the characteristics of the main European glass sector: container glass. Its trends and performance improvements are then analysed in Section 3 to assess the suitability of the sustainability routes adopted and programmes launched for achieving more sustainable and competitive performance. Finally, the experience of the Italian container glass sector is investigated in Section 4, highlighting the achieved goals and faced challenges. The results indicate the need for better separate collection management of container glass, especially in some areas in southern Italy. This represents the key critical issue and weakness in order not only to embrace sustainability as a business imperative, but also to adopt models promoting systemic changes towards circular economy goals. The conclusions are presented in Section 5, and highlight that container glass stands out as one of the most successfully recycled materials, not only for its intrinsic characteristics, but also for the well-established separate collection schemes adopted at the European Union (EU) level and also in some Italian regions. Waste glass containers are capable of operating in an efficient closed-loop system if well-supported by efficient municipal solid waste management.

\section{Background}

\subsection{A Brief Historical Overview}

Since the Stone Age, people have used naturally occurring glass formed from common elements present in the earth's crust, fused by high volcanic heat, and vitrified by rapid air cooling. Pliny the Elder, in his Naturalis Historia, places the discovery of glass by certain merchants in today's southern Lebanon, where analyses of the sand of the Belus river have revealed high-silica sand containing sufficient quantities of calcium components [15]. The date of the first production of man-made glass is uncertain, because it is lost in time, but was first probably developed in a region of Mesopotamia [16].

Around 1500 B.C., glass manufacture appeared as a major industry in Egypt [17]. The fundamental breakthrough in glassmaking was the discovery of blowing in the last century B.C., and the ancient Romans greatly increased the variety of shapes for hollow glass items and successively began to use glass for an architectural purpose. The Romans also spread glassmaking technology through conquests and trade relations across western Europe and the Mediterranean. The Roman tradition of very fine glass products did not continue in the Middle Ages, when Venice assumed the role of glassmaking centre of the western world [18].

In 1291, the Venetian authorities ordered a transfer of glass manufacturing for fire safety reasons to the island of Murano, where in the second half of the 15th century, craftsmen started to produce crystal using quartz sand and potash from sea plants. To this day, the island remains a world-renowned centre for fine glassware. The subsequent development of lead glass crystal has been attributed to the English glassmaker George Ravenscroft [19], who patented this new product in 1674. In the same period (i.e., in 1688), an innovative process was developed in France to produce plate glass, mainly for high quality mirrors and optical products. 
It was only in the latter stages of the Industrial Revolution that mechanical innovations for the mass production of glass and scientific research on glass composition, its properties, and applications took place.

Modern glass technologies make use of important discoveries, mainly related to automation processes, occurring in different sectors of the glass industry. Consider, for example, Michael Owens' bottle-blowing machine invented in the early years of the 20th century, or the automated production of the Belgian Fourcault, which managed to draw vertically a continuous sheet of glass from a tank, or to the latest technological innovation known as the 'float process'. In this latter process, developed after the Second World War by Britain's Pilkington Brothers Ltd., molten glass is poured across the surface of a bath of molten tin, forming a floating ribbon with perfectly smooth surfaces on both sides.

Obviously, technological innovations continue, using multiple contributions from the most diverse scientific fields, ranging from electronics to chemistry, from nanotechnologies to space engineering, from life science engineering to renewable energy, biotechnology, etc.

\subsection{The European Glass Industry Landscape}

The European global glass production for 2006-2015, reported in Figure 1, shows that after a drop in production in 2009 (32.2 Mt), it is currently at almost the same level as it was 10 years ago (around $36 \mathrm{Mt}$ ).

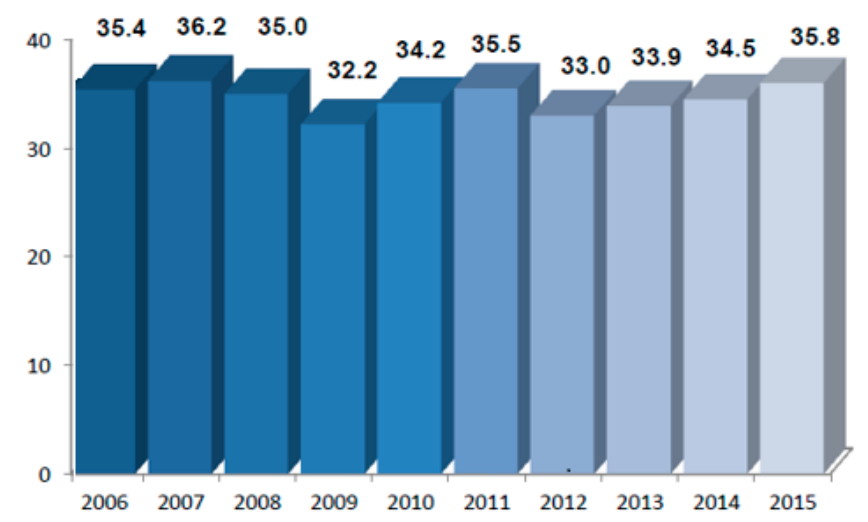

Figure 1. European Union (EU) Glass Production 2006-2015 (Mt) [20].

Figure 2 shows the evolution of European glass production (Mt) by sector during 2006-2015.

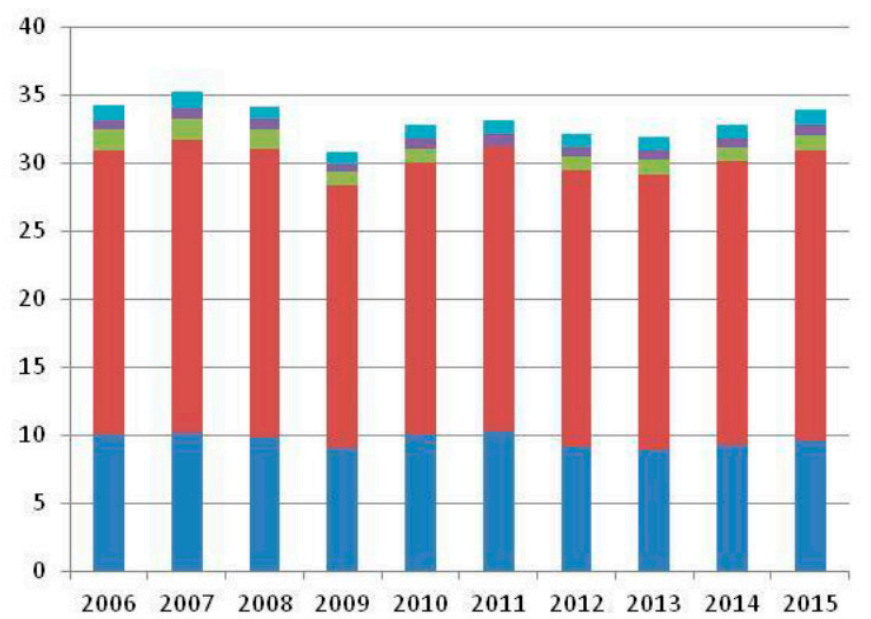

Flat glass $\square$ Container $\square$ Domestic $\square$ Reinforcement Glass Fibre $\square$ Others

Figure 2. European evolution of glass production by sector (2006-2015) (Mt) [21]. 
The two most important European glass sectors are container and flat glass, accounting for about $70 \%$ and $25 \%$, respectively, of total glass production, followed by the combined production of domestic glass $(2 \%)$, continuous-filament glass fibre ( $2 \%)$, and special glass $(1 \%)$ [22].

The European container glass industry is capital intensive, and with its 160 manufacturing plants, employs directly about 50,000 individuals, representing a fundamental part of Europe's packaging sector as well as an important contributor to its economy. It produces high-quality glass packaging products for food and beverages in addition to flacons for perfumery, cosmetics, and pharmacy for the global market. Glass packaging is a resource-efficient and endlessly recyclable material, which makes it a useful packaging resource in the context of sustainable consumption and production [21].

The flat glass sector includes all glass produced in flat form, regardless of the type of manufacturing process involved. There are two types of flat glass production processes: float and rolled glass. The first, used in about 50 plants, dominates the sector's output (over $95 \%$ of total flat glass production in Europe). The end-products of the float process, large sheets of glass, are fairly homogeneous and are often further processed to give the glass specific characteristics. The sector employs directly approximately 15,000 individuals and many more in downstream treatment. The two most important markets for flat glass are the building (windows and facades) and automotive industries (windscreens, side- and rear-side glazing, etc.), followed by solar energy applications (photovoltaic and thermal panels) [21].

The domestic glass sector accounts for more than 300 facilities, mainly small and medium enterprises, and comprises the manufacturing of glass tableware, cookware, and decorative items such as drinking glasses, bowls, plates, cookware, vases, and ornaments [21].

The European glass fibre sector employs directly approximately 5000 individuals, and produces principally continuous filament glass fibres known as fibre-reinforced polymers or glass-reinforced plastics. These products have a relatively high value-to-mass ratio, and are mainly used to produce composite materials as weight-lightening reinforcement components in sectors ranging from the automotive and transportation (e.g., aircraft) sectors to the wind energy, agriculture, construction, communication, electrical, electronic, and sport and leisure sectors [21].

The special glasses sector regroups a large range of products, such as lighting glass, glass tubes, laboratory glassware, glass ceramics, heat-resistant glass, optical and ophthalmic glass, and extra thin glass for the electronics industry, having a high added value due to the intense technological content.

The extreme diversity of the European glass industry is not only in the products made, but also in the manufacturing techniques employed. For instance, manufacturing techniques vary from the small electrically heated furnaces in the high-temperature insulation wools sector to the cross-fired regenerative furnaces in the flat glass sector, producing up to $1000 \mathrm{t}$ per day. This industry also includes many smaller installations that fall below the $20 \mathrm{t}$ per day threshold. Natural gas is the primary source of fuel in European glass production, typically accounting for more than $70 \%$, while electricity accounts for around $25 \%$, and other fuels (mainly fuel oil) make up the remaining $5 \%$. Melting furnaces-employing combustion-heating (with air- or oxy-fuel burners), direct electrical heating, or a combination of the two (electric boosting) - are the major energy users. Usually, the energy necessary for melting the glass may account for around $75 \%$ of the total energy (in terms of final energy) requirements of glass manufacture [22]. Typically, melting furnaces operate with an overall efficiency of 50-60\%, where structural and flue gas losses represent, respectively, $20-25 \%$ and $25-35 \%$ of total losses [5]. Therefore, melting furnaces are the most important for improving technological efficiency in glass manufacturing, followed by refining and conditioning [23].

Until the mid-1970s, manufacturing industries with higher energy and raw material intensities, such as the glass industry, accrued large efficiency savings, improving resource productivity and minimizing environmental impacts as a result of the significant increase in energy prices after the oil crises in the 1970s. Over time, a greater awareness of the complex environmental implications of many industrial activities has emerged worldwide, leading policy-makers and institutions responsible for protecting the environment and safety to increase legislative pressure and implement various 
policies and measures. In the late 1990s, the glass industry went through a period of reorganization to reduce costs and compete more effectively in the global market. To benefit from economies of scale, companies merged, and the groups dominating the sector became more international in their operations.

Particularly, the decoupling of both energy and natural resource demand from economic growth has been attempted through the adoption of a wide range of mandatory and voluntary tools. Over the past decades, the European glass industry has applied various measures, such as technological innovations spanning both plant modernization, improvements in material and energy efficiency, and a higher substitution of primary raw material with cullet and fuel oil with natural gas, to promote competitiveness and environmental performance. The main reasons are due to the coming into force of the Industrial Emissions Directive (IED) 2010/75/EU and the legislative proposal of the EU ETS revision, presented to the European Commission in July 2015 for phase 2021-2030 (phase 4), in line with the EU 2030 Climate Energy Policy Framework, to reduce EU GHG emissions by $43 \%$ compared to 2005.

The IED Directive outlines EU-wide thresholds for air and water emissions for different industrial sectors, applicable from 2016 onward. The thresholds for 'Manufacture of Glass' are determined by the Best Available Techniques (BAT) Reference Document (BREF), originally adopted by the European Commission in 2001 and revised in 2013, that defines permit conditions for glass installations in Europe. Important issues for the implementation of Directive 2010/75/EU in glass manufacturing are the reduction of air polluting emissions; the efficient use of energy and raw materials; the minimization, recovery, and recycling of process residues; and the effective implementation of environmental and energy management systems. This will possibly determine the investment for future environmental measures in the European glass industry to increase considerably: by 2020, about EUR 14 billion will be invested, with an annual increase of up to $45 \%$ [24]. Based on BAT Reference data [3] (p. 92), the melting energy requirements experienced in the various glass sectors vary widely, from about 3.3 to over $40 \mathrm{GJ} /$ melted $\mathrm{t}$. However, most European glass is produced in large furnaces and the average direct energy requirement for melting is generally around $8 \mathrm{GJ} / \mathrm{t}[1,3,25]$. For the container glass industry, fuel and direct $\mathrm{CO}_{2}$ intensity result in an average of $6.4 \mathrm{GJ} / \mathrm{t}$ and $0.48 \mathrm{tC} 02 / \mathrm{t}$, respectively [2].

The final energy consumption (fuel and electricity) and total $\mathrm{CO}_{2}$ emissions (direct or verified emissions from process and combustion, and indirect emissions from electricity utilization) for the European glass industry (EU25/27), and its sub-sectors, based on data gathered in the framework of the European Union-Emission Trade System (EU-ETS) during 2005-2007 (phase 1) has been reported by Schmitz et al. in 2011. The overall final energy consumption (2007) of the EU25 and EU27 was, respectively, $344 \mathrm{PJ}$ and $352 \mathrm{PJ}$, with a share of electricity of around $17 \%$. The European container glass industry contributed 46\%, by $158 \mathrm{PJ}$ (EU25) and $161 \mathrm{PJ}$ (EU27). Overall, $\mathrm{CO}_{2}$ emissions (direct and indirect) were, respectively, 26.9 Mt (EU25) and 27.5 Mt (EU27) for the global glass industry, and 12.4 Mt (EU25) and 12.6 Mt (EU27) for the container glass industry, of which about $80 \%$ are direct emissions (combustion and process emissions).

The specific energy consumption for glass products and related emission data are provided in an aggregate form due to restrictions derived mainly from competition issues [3] (p. 407). Unfortunately, this limitation does not allow for a comprehensive analysis on the various industrial approaches adopted by major European glass producing countries so as to compare improvements in resource efficiency and pollution reduction.

The lack of public data both at the European and national levels concerning final energy consumption and the different energy sources used in various glass sectors limit the provision of a benchmark related to the best practices developed to date, as well as the suitability of sustainability initiatives implemented.

The European glass industry has been particularly affected by the economic crisis, since its activity relies heavily on the economic health of other sectors, such as the construction and automotive as well as packaging sectors. This could severely limit the investment capacity that would address issues 
related to the environmental performance required by the IED Directive. Weak economic growth and slower domestic demand are specifically due to austerity policies at the European level and together account for the crisis affecting this sector.

Between 2005 and 2010, flat glass was affected by a 7\% decrease in production following the crisis of 2008, and, in 2013, 15 out of a total of 60 floats in Europe have ceased production. Several have closed or are in danger of disappearing. Following a constant increase in demand until 2007 for flat glass, from 2008 onwards the demand dropped sharply due to a decrease in the production of the automotive industry, together with the relocation of assembly lines, competition from China for solar panels, and the slowing down of the construction sector. These four factors have resulted in an unexpected $20 \%$ overcapacity for floats due to the traditionally risky strategies of multinational companies. From 2000 to 2010, the sector lost 32\% of its jobs, mainly in Germany, Poland, France, the Czech Republic, Italy, Belgium, and Austria [26].

Meanwhile, during the same period, the European container glass sector has experienced a decrease of more than $10 \%$ because of the economic crisis and the relocation trend. The same pattern was observed in the glass fibre sector, as many producers have had to temporarily shut down some of their furnaces to adapt to the volatile market demand, which led to the postponement of several investment projects. However, this sector now appears to be picking up once more [26].

\section{The EU Container Glass Industry between Competitiveness and Sustainability for Improving Circular Economy}

This section provides background information on the European container glass industry, the biggest producer of container glass worldwide. Glass containers are produced in a two-stage moulding process, using pressing and blowing techniques. The five essential stages involved in automatic bottle production are: obtaining a piece of molten glass (gob) at the correct mass and temperature; forming the primary shape in a first mould (blank mould) by pressure from compressed air (blow) or a metal plunger (press); transferring the primary shape (parison) into the final mould (finish mould); completing the shaping process by blowing the container with compressed air to the shape of the final mould; and removing the finished product for post-forming processes [3] (pp. 53-54). Glass containers are produced in glass furnaces of different sizes and employing different technologies by melting together raw materials and cullet from the scrap glass generated at a glass manufacturing site, used as an internal loop, and external cullet, including recycled container glass and smaller amounts of cullet from flat glass waste.

The global production of container glass was around $49 \mathrm{Mt}$ in 2014 and is estimated to surpass $59 \mathrm{Mt}$ by 2020. The annual production of glass containers in the Asia-Pacific region (APAC) countries was around $16 \mathrm{Mt}$ in 2014 and is estimated to reach around $20 \mathrm{Mt}$ by 2020. In 2014, the glass container market in APAC was dominated by China, while the fastest growth rate is expected for India [27]. The total European glass container production in 2014 exceeded $22 \mathrm{Mt}$, an increase of approximately $10 \%$ compared to 2009 (around $20 \mathrm{Mt}$ ). The main producing country is Germany (almost $4 \mathrm{Mt}$ ), followed by Italy (about $3.5 \mathrm{Mt}$ ) and France (about $3 \mathrm{Mt}$ ). These three countries, together with the United Kingdom (2.2 Mt) and Spain (2.1 Mt), contribute to around 70\% of EU28 production (Table 1). Most European countries have maintained over the past five years an almost constant production. At the same time, other countries, such as Poland, Portugal, and Turkey, have recorded significant increases, respectively by $9.3 \%, 10.5 \%$, and $50.4 \%$.

The industry contributes EUR 9.5 billion yearly to the EU GDP, and has an impact on Europe's trade balance of EUR 21 billion for products primarily packed in glass, maintaining 125,000 direct and indirect jobs [29].

Glass container manufacturing is one of the most material- and energy-intensive industrial processes, consuming large amounts of non-renewable resources and thermal energy, mainly fuelled by natural gas, because high temperatures (up to $1550{ }^{\circ} \mathrm{C}$ ) are needed for melting the raw materials. As a result, it is also $\mathrm{CO}_{2}$ emissions-intensive through the combustion of fuels, as well as through the 
decomposition of carbonates (decarbonation). The use of cullet in closed-loop cycles is helpful both in terms of environmental protection and energy and resources savings, allowing for a reduction in a product's or process's ecological footprint. As a general rule, a 10\% increase of cullet into container glass melting mass decreases the energy consumption by about 2-3\% [3] (p. 92) and $\mathrm{CO}_{2}$ emissions by $5 \%$ [29], as the substitution of raw materials containing carbonate also reduces $\mathrm{CO}_{2}$ process emissions released by decarbonation. Indeed, melting $1 \mathrm{t}$ of cullet saves not only around $1.2 \mathrm{t}$ of virgin raw materials, but cuts overall $\mathrm{CO}_{2}$ emissions (direct and indirect) by around 60\% [30].

Table 1. European glass container production (2010-2014) (t) [28].

\begin{tabular}{ccccccc}
\hline Country & $\mathbf{2 0 1 0}$ & $\mathbf{2 0 1 1}$ & $\mathbf{2 0 1 2}$ & $\mathbf{2 0 1 3}$ & $\mathbf{2 0 1 4}$ & Growth 2010-2014 (\%) \\
\hline Germany & $3,787,7500$ & $4,065,452$ & $3,934,844$ & $3,933,641$ & $3,973,786$ & 4.9 \\
Italy & $3,506,532$ & $3,568,710$ & $3,391,637$ & $3,445,302$ & $3,467,462$ & -1.1 \\
France & $3,152,023$ & $3,310,186$ & $3,146,755$ & $3,030,949$ & $3,097,473$ & -1.7 \\
United Kingdom & $2,316,604$ & $2,310,667$ & $2,226,321$ & $2,240,759$ & $2,245,986$ & -3.0 \\
Other North-Central & $1,950,400$ & $2,041,404$ & $2,096,753$ & $2,093,984$ & $2,138,703$ & 9.6 \\
Spain & $1,979,957$ & $2,067,016$ & $2,012,381$ & $2,087,000$ & $2,099,236$ & 6.0 \\
Portugal & $1,312,909$ & $1,351,919$ & $1,441,962$ & $1,439,429$ & $1,451,735$ & 10.6 \\
Other South-East & $1,068,659$ & $1,186,726$ & $1,198,207$ & $1,364,601$ & $1,403,563$ & 31.3 \\
Turkey & 779,462 & 822,502 & 950,000 & $1,021,000$ & $1,172,313$ & 50.4 \\
Poland & 986,347 & 986,750 & 996,660 & $1,003,551$ & $1,078,071$ & 9.3 \\
Total Europe & $20,840,643$ & $21,711,331$ & $21,395,520$ & $21,660,216$ & $22,128,328$ & 6.2 \\
Total EU28 & $19,956,884$ & $20,783,077$ & $20,333,593$ & $20,533,216$ & $20,858,515$ & 4.5 \\
\hline
\end{tabular}

Notes: Figures are the total production for packed bottles and jars for food and drink and flacons in tonnes. Other North-Central: Austria, Belgium, Denmark, Estonia, Finland, Netherlands, Sweden, Switzerland. Other South-East: Bulgaria, Croatia, Czech Republic, Greece, Hungary, Romania, Slovakia.

Although significant effort has been made by the upstream European container glass industry, especially through cullet recycling whose rate has increased from $43 \%$ in 1990 to $71 \%$ in 2013 [31], further improvements are required to reduce its global environmental footprint, enhancing not only cullet use but also improving its quality. Indeed, broken and mixed glasses of different colours are economically and technologically difficult to reuse for the fabrication of new glass products, because these materials can cause a variation in the chemical composition of recycled glass, thus affecting the properties of new glass produced [32-34].

Container glass, after use, can be collected either separately or by following municipal household waste treatment. For collection, the container glass is sent to cullet treatment plants (CTP), where it is separated into cullet and impurities (paper, metal, plastic, small fractions of glass), which are disposed of in landfills (metals are usually recycled). After CTP, cullet can be recycled into container glass production (closed-loop system); used for other products, including construction materials for embankments and pavement subbases [35]; used in cement and concrete production as supplementary cementitious material or aggregates [36-38]; or used as lightweight fill material in civil engineering applications $[39,40]$. This latter approach offers a viable solution to two problems: reducing cement and concrete carbon emissions, and diverting waste from landfills. This is a paradigmatic example of cascading a material to another valuable use and implementing a virtuous circle, one of the key principles of value creation in the circular economy. This is in line with the strategy for the development of circular economy models launched by the European Commission through a legislative package in December 2015 [41].

Container glass products hold a special place in the circular economy, as glass has been defined a 'permanent material', since it is totally and endlessly recycled without any degradation of its properties. The first mention of 'permanent materials' in European legislation dates to 2012, in the resolution for a Resource Efficient Europe. From a Sustainable Development viewpoint, 'Permanently available materials are those for which efforts are made to retain for use in society the energy and raw materials invested in their production at the end of product life, either through reuse or recycling, with no loss of quality no matter how many times the material is recycled' [42]. For glass containers, the 2015 
legislative package increased the $60 \%$ target set by Directive $94 / 62 / \mathrm{CE}$ to $75 \%$ by 2025 and $85 \%$ by 2030 .

In 2013, in EU28, over than 70\% of all post-consumer glass packaging was recovered, keeping valuable resources out of landfills. This result makes Europe the continent with the highest recycling rates worldwide. Figure 3 shows the different performances of European member states. Denmark, Belgium, Sweden, Switzerland, Luxemburg, Norway, and Austria continue to be the best performers, recording striking rates; Germany, Netherlands, and Italy improved their performance from previous years, achieving, in 2013 , rates of $88 \%, 79 \%$, and $76 \%$, respectively.

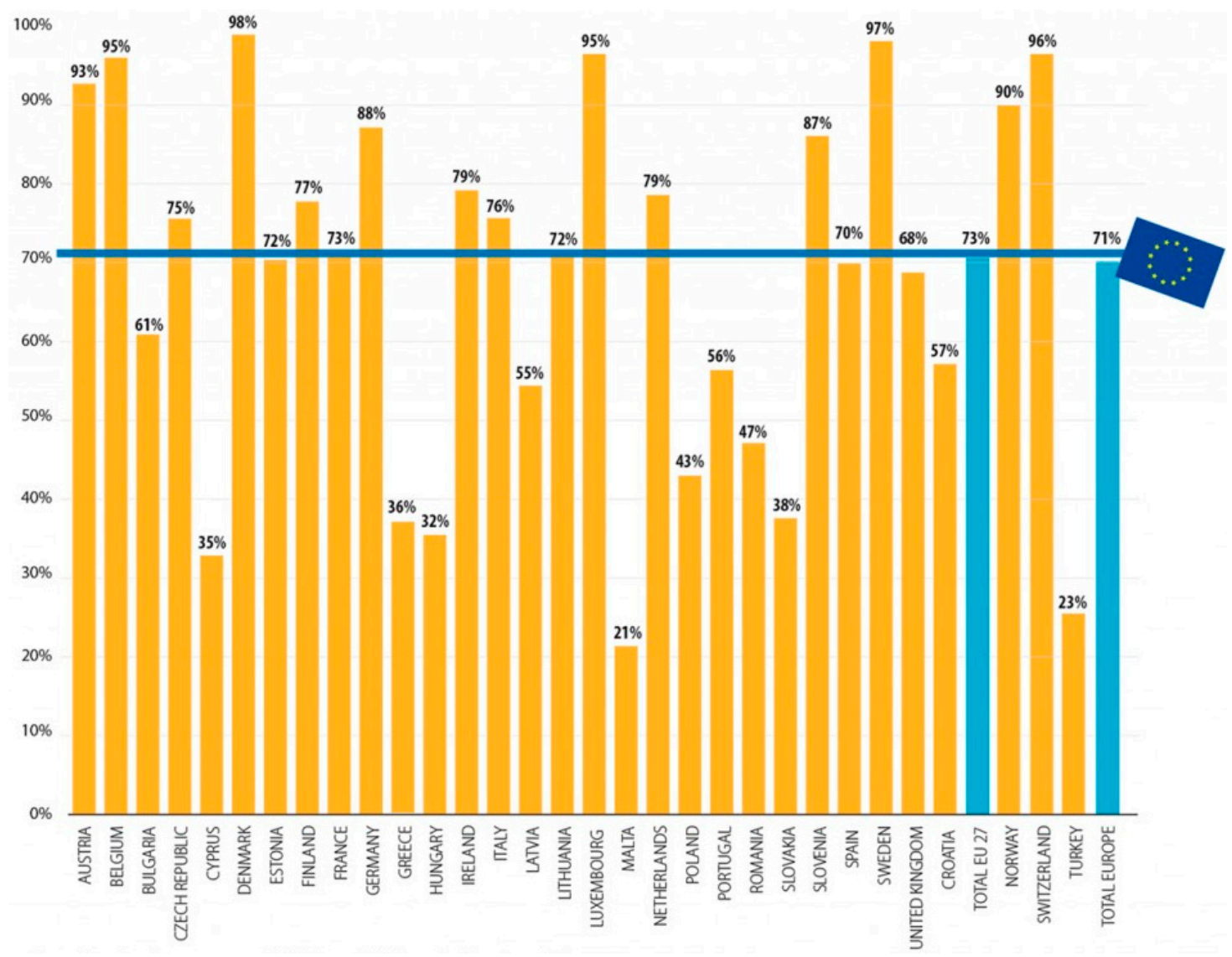

Figure 3. Collection for the recycling rates of containers glass in Europe, 2013 [43].

The European container glass sector will face further challenges in a future business scenario whereby both upstream initiatives, such as further technological improvements in resource and energy efficiency and cutting emissions, lightweight products, and downstream initiatives related to more robust support for waste glass packaging management, provide opportunities for achieving more sustainable and competitive global performance. This identifies the most appropriate pathway to promote, over the next decades, energy and material efficiency, as well as low carbon emissions, by fostering a circular economy approach based on systemic networks, with the ability to promote a radical shift in how materials move through the economy, highlighting the importance of the inter-relationships between multiple organizations and how this interaction could represent sustainable product-service solutions as an important source of competitive advantage [44].

As such, improved process control, increased cullet percentage, enhanced waste glass collection, better furnace size, the use of waste heat in batch and cullet preheating or steam generation, the use of oxy-fuel technologies, and the reduction of rejects are major energy- and resources-saving efficiency opportunities for the competitiveness of the European container glass sector [22]. 


\section{Circular Economy for Container Glass Sector: Evidence from Italy}

Waste management represents a great challenge for the Italian landscape because Italy has traditionally landfilled most of its municipal solid waste. Nevertheless, starting from the late 1990s, there has been a significant effort to increase the recovery of municipal waste; consequently, landfill rates have decreased between 2001 and 2015 from $68 \%$ to $26 \%$ [45,46].

Figure 4 highlights the common waste sorting and recycling framework adopted in Italy [47], and recent studies have shown real energy and environmental benefits in recycling some types of packaging waste, among which is glass [48,49].

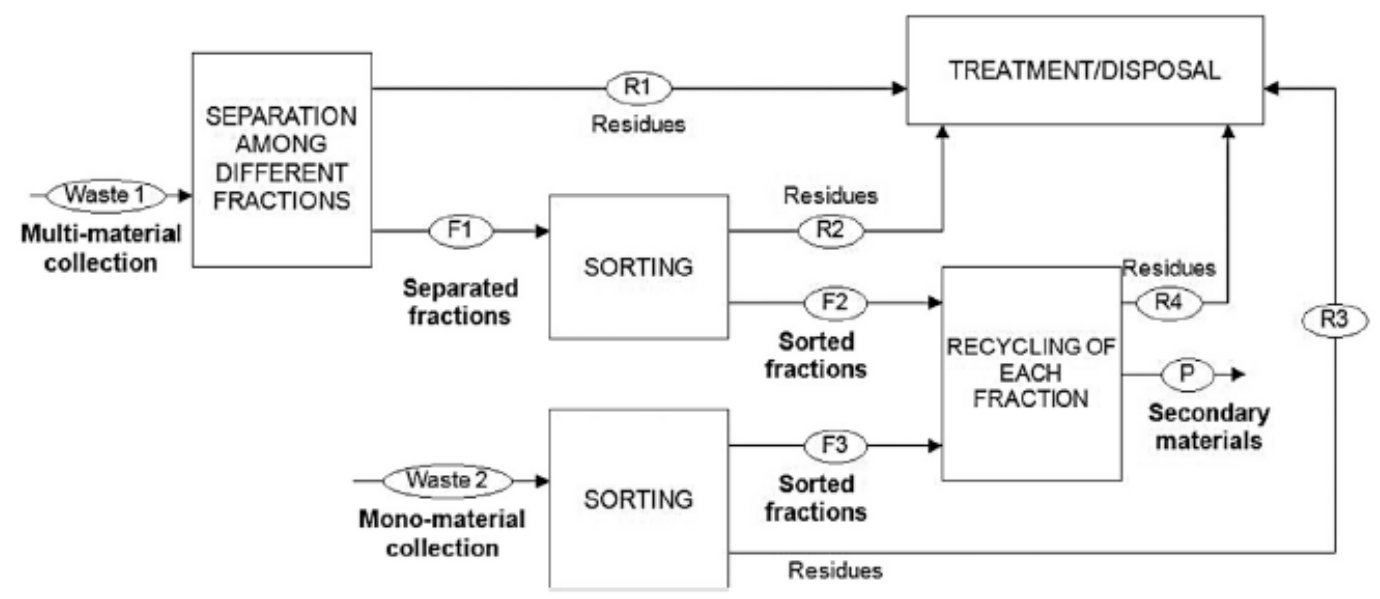

Figure 4. General scheme of packaging waste separation, sorting, and recycling in Italy ( $\mathrm{R} \frac{1}{4}$ residues; $\mathrm{F} \frac{1}{4}$ fractions; P $\frac{1}{4}$ products) [47].

We report below remarkable Italian data related to the container glass sector (Table 2), the separate collection of glass packaging (Figure 5), disposed packaging glass versus recycling rates (Figure 6), the amount of disposed and recycled packaging waste in 2015 (Figure 7), the trend of packaging released to the market, the recycled and recycling rate of packaging waste during 2006-2015 (Table 3), the framework of cullet recycled in the Italian container glass industry in 2015 (Figure 8), and the main benefits associated with cullet recycled in 2015 (Figure 9).

Table 2 shows data on Italian container glass production, imports, and exports during 2006-2014, with a production increase of $12 \%$, an import increase of more than $60 \%$, and an export decrease of about $1 \%$.

Table 2. Italian production, import, export of container glass (2006-2015) (kt) [50,51].

\begin{tabular}{cccc}
\hline Years & Production & Import & Export \\
\hline 2006 & 3644 & 458 & 570 \\
2007 & 3695 & 475 & 539 \\
2008 & 3808 & 531 & 558 \\
2009 & 3500 & 480 & 448 \\
2010 & 3778 & 623 & 502 \\
2011 & 3835 & 641 & 519 \\
2012 & 3679 & 650 & 507 \\
2013 & 3658 & 600 & 536 \\
$2014^{*}$ & 3949 & 694 & 531 \\
$2015^{*}$ & 4076 & 743 & 557 \\
\hline
\end{tabular}

Note: Since 2014, the methodology for the compilation of national statistics has changed. 
Figure 5 underlines the trend of separate collection of glass packaging $(\mathrm{kt})$, which increased by about $32 \%$ from 2006 to 2015 . In Italy, the separate collection of glass packaging waste is mainly managed $(90 \%)$ by the CoReVe Consortium, and the remaining part is managed independently. The responsibility for the management of packaging waste in Italy is generally transferred by the industry to CONAI, the National Packaging Consortium, a private non-profit organization established in 1997 with the aim of promoting the separate collection, sorting, recovery, and recycling of packaging waste. For the recovery operations of different materials, CONAI co-ordinates the activities of some Material Consortia, among which is CoReVe [52].

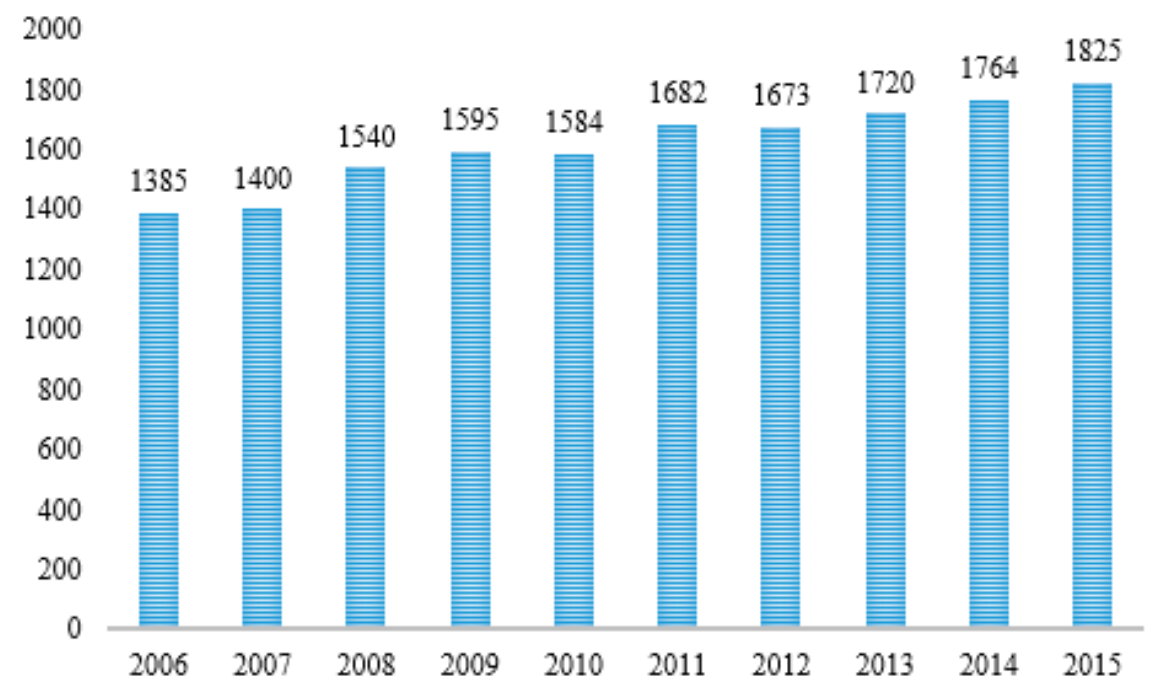

Figure 5. Separate collection of glass packaging (2006-2015) (kt) [53].

Figures 6 and 7 explain, respectively, the trend for the recycling rates and disposed glass packaging waste during 2006-2015 in Italy, and the amount of container glass waste recycled and landfilled in 2015. The data show that the $60 \%$ target set by the EU has been exceeded, even if nearly $700,000 \mathrm{t}$ of glass packaging has converged to municipal waste, to which waste coming from selection and treatment plants is added.

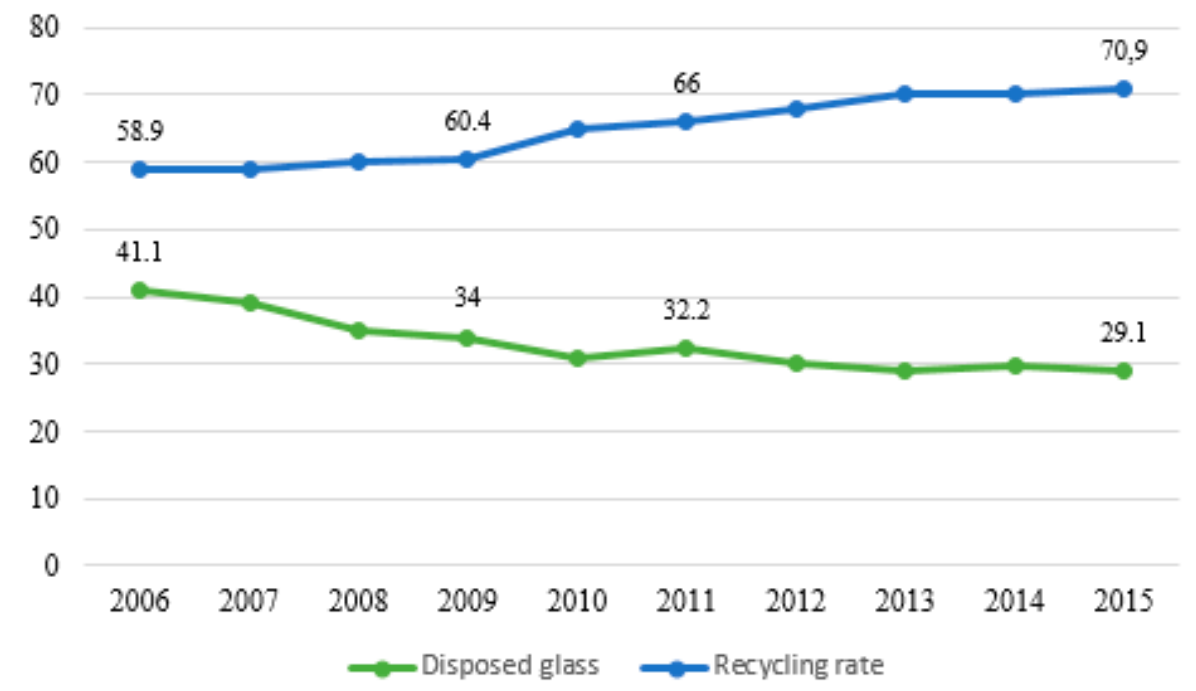

Figure 6. Recycling rate of waste from glass packaging (2006-2015) (\%) [53].

Figures 8 and 9 highlight, respectively, the framework of cullet recycled and the main benefits associated with the use of cullet in the Italian container glass industry (2015). 
Released to the market: $2,342,845 \mathrm{t}$

(2015)

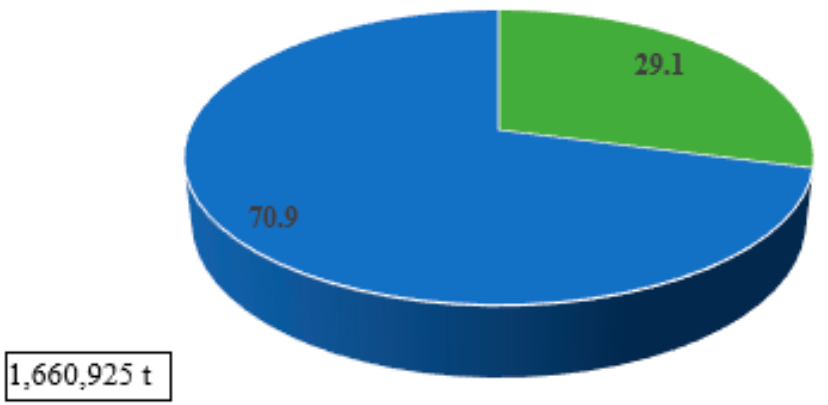

- packaging waste disposed - recycled packaging waste

Figure 7. Waste glass packaging recycled and disposed in 2015 (\%) [53].

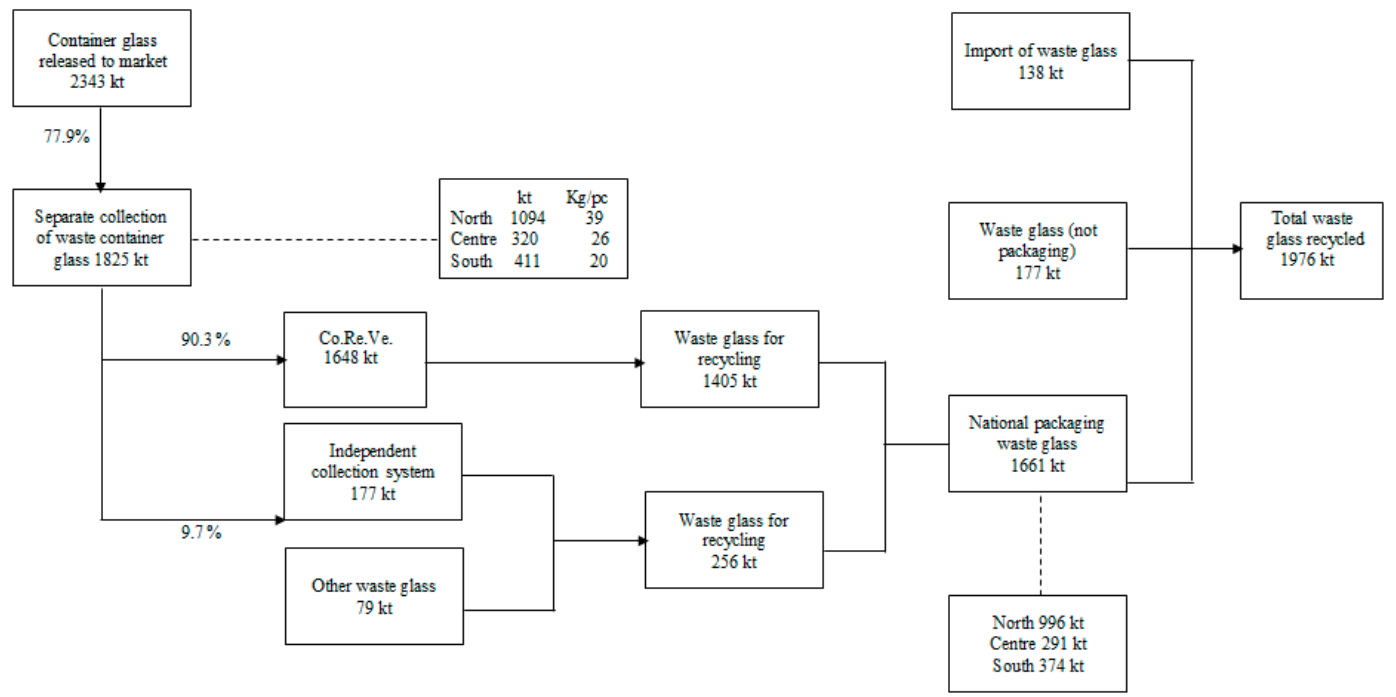

Figure 8. Cullet for recycling in the Italian container glass industry (2015).

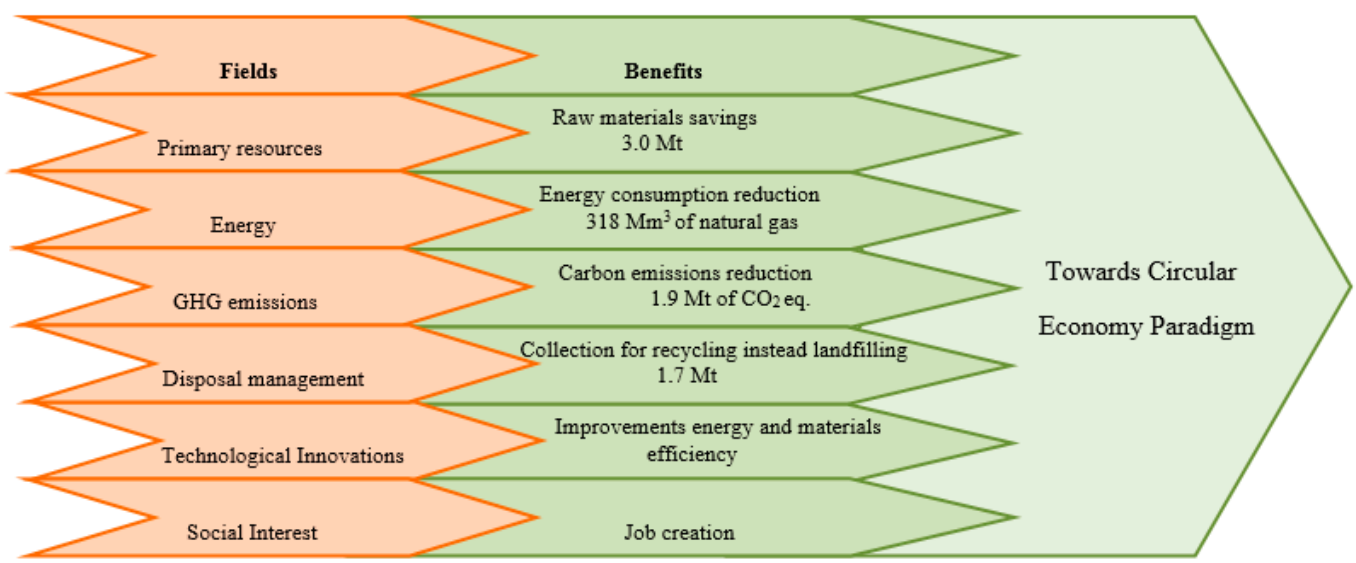

Figure 9. Synthesis of main benefits of cullet recycling in the Italian container glass industry (2015). Data processed by $[53,54]$. GHG: greenhouse gas. 
Table 3 shows data for 2006-2015 and highlights that, if the glass packaging increases in Italy by about $10 \%$, the amount of recycled glass increases by $32 \%$.

Table 3. Released to the market, glass recycled, and recycling rate (2006-2015) [53-55].

\begin{tabular}{ccccccccccc}
\hline & $\mathbf{2 0 0 6}$ & $\mathbf{2 0 0 7}$ & $\mathbf{2 0 0 8}$ & $\mathbf{2 0 0 9}$ & $\mathbf{2 0 1 0}$ & $\mathbf{2 0 1 1}$ & $\mathbf{2 0 1 2}$ & $\mathbf{2 0 1 3}$ & $\mathbf{2 0 1 4}$ & $\mathbf{2 0 1 5}$ \\
\hline Released to the market (kt) & 2133 & 2156 & 2139 & 2065 & 2153 & 2266 & 2212 & 2255 & 2298 & 2343 \\
Odds (\%) & 0.8 & 1.1 & -0.8 & -3.5 & 4.3 & 5.2 & -2.4 & 1.9 & 1.9 & 1.9 \\
Recycled (kt) & 1256 & 1303 & 1390 & 1362 & 1471 & 1570 & 1568 & 1596 & 1615 & 1661 \\
Odds (\%) & 3.7 & 3.7 & 6.7 & -2.0 & 8.0 & 6.7 & -0.1 & 1.8 & 1.2 & 2.9 \\
Recycling rate (\%) & 58.9 & 60.4 & 65.0 & 66.0 & 68.3 & 69.3 & 70.9 & 70.8 & 70.3 & 70.9 \\
\hline
\end{tabular}

Note: The historical series of released to the market have been rectified since 2011.

A deeper analysis of the above data illustrates diverse realities. In 2015, very different performances have been achieved in northern, central, and southern Italy, with a recycling rate of $73 \%, 64 \%$, and $55 \%$, respectively [54]. In fact, only northern Italy is in line with European targets, as by 2025 it will only have to increase its current performance by two percentage points, unlike the central and southern areas that will have to increase their current performance, respectively, by about $11 \%$ and $20 \%$ (Figure 10) $[55,56]$.

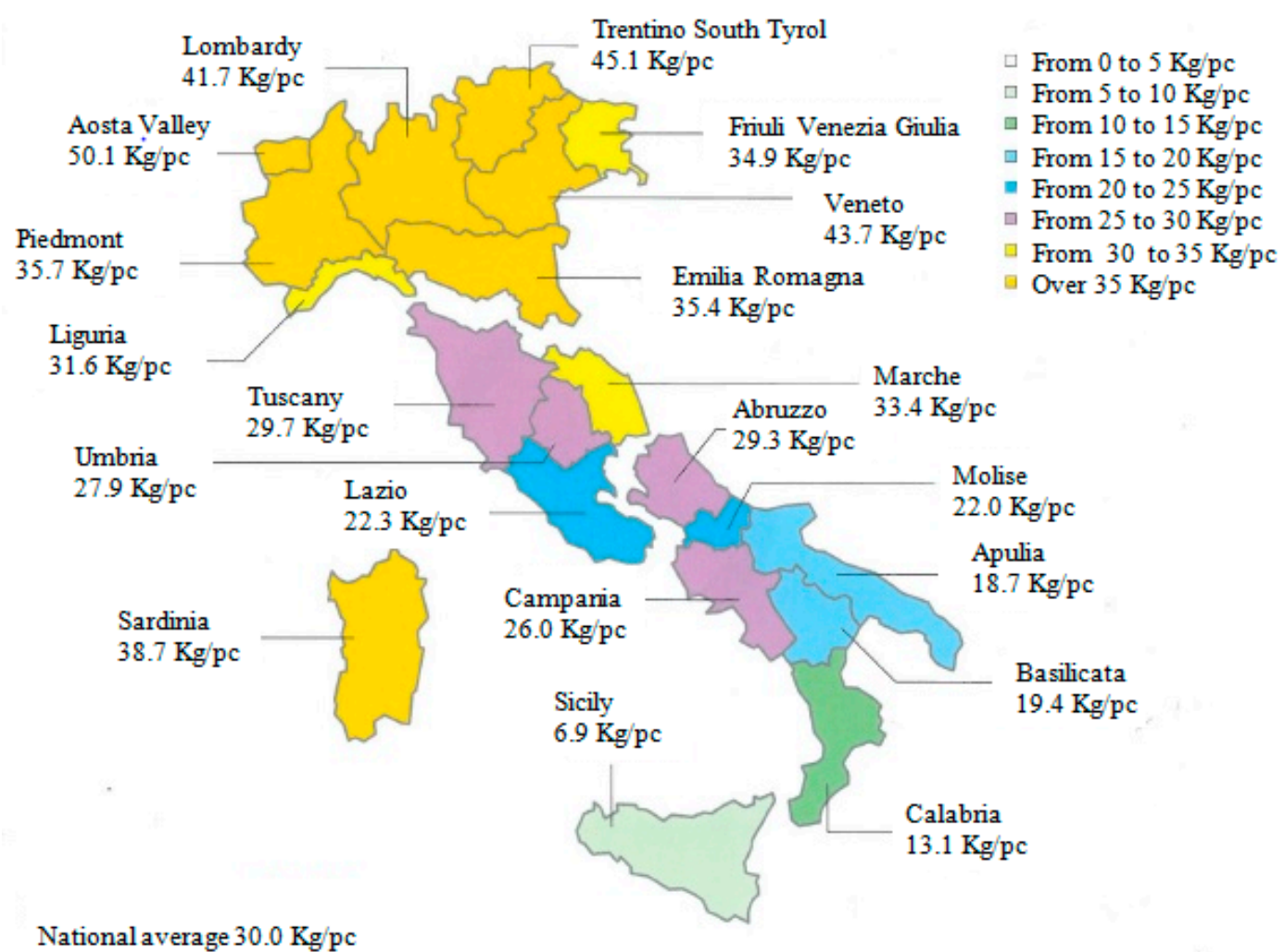

Figure 10. Regional data (kg/pc) of recycled glass packaging waste in Italy (2015) [55].

In February 2017, CoReVe [57] presented a special plan to encourage glass recycling in seven regions in southern Italy (Abruzzo, Basilicata, Calabria, Campania, Molise, Puglia, and Sicilia). Through this initiative, operators will help increase regional recycling targets by at least $10 \%$ in terms of quantity (around $60 \mathrm{kt}$ ) compared to 2016, and the respective regions will receive a money prize (extra bonus) [57]. In addition to the extra bonus, the CoReVe is also available to support managers with know-how.

This scenario shows the need to improve the quantitative efficiency of waste collection systems in the central and southern regions, where undifferentiated waste still has appreciable amounts of glass, 
estimated at more than half a million tonnes. The delay of southern regions puts at risk all Italy toward reaching the new EU targets.

Furthermore, of the waste arising from the Italian processing of collected container glass (i.e., $150,000 \mathrm{t}$ ), as much as $90 \%$ consists of glass that remains unused, and only $10 \%$ represents non-recyclable materials in the glass industry (ceramic, crystal, etc.) [54]. Over the past five years, due to an increase in the 'quantity' of collected glass waste, the amount of unused waste has also increased contextually, thus revealing the absence of a 'qualitative' improvement in performance. A recent CoReVe analysis shows (Table 4 ) that the unused waste percentages vary greatly (from $4 \%$ to $35 \%$ ) depending on the separate collection systems adopted.

Table 4. Unused waste percentages by collection system. [53].

\begin{tabular}{ccc}
\hline Separate Collection System & $\begin{array}{c}\text { Recycled from Total } \\
\text { Collected Glass (\%) }\end{array}$ & Effective Waste (\%) \\
\hline Bell only glass & 96 & 4 \\
Bell glass and metal & 92 & 8 \\
Door-to-door only glass & 90 & 10 \\
Door-to-door glass and metal & 79 & 21 \\
Road container for glass, metal, and plastic & 65 & 35 \\
\hline
\end{tabular}

As Table 4 highlights, separate collection through a dedicated bell maximizes the percentage of glass that can be recycled an infinite number of times without quality loss. In various European countries, the bottle bank's colour and shape have been established, allowing excellent results. However, there are some factors that greatly limit diffusion. For instance, the development of urban areas and certain city configurations, namely old city centres, make it difficult to use large-capacity bottle banks and have site access for collection trucks. In Austria or Belgium, underground bottle banks are already implemented in some cities, representing a viable solution [58].

Door-to-door collection is an option to overcoming some limitations, but reduces not only efficiency, but makes the collection system more expensive, especially if glass is collected together with metals (Table 4). The road containers for glass, metal, and plastic are the least efficient system, since only $65 \%$ of glass is recycled from the total glass collected (Table 4 ).

Glass containers are mainly produced in three colours, clear, green, and amber, but the mixed coloured cullet can be used only for green glass production, while the manufacturing of clear or flint glass, and, to a lesser extent, amber glass, require cullet of the same colour. As such, mixed colours can result in an excess of production capacity for green glass furnaces. In countries such as Germany, Austria, Belgium, Switzerland, and the U.K., systems to separate bottles and jars by colour (double or triple separation) are implemented, improving glass recycling rates and preventing cullet surpluses to have a negative impact on the glass recycling market.

Waste prevention, recycling, and better waste management, in general, are crucial to minimizing flows into and out of the economy, closing the material loop, and preventing further impacts on the environment and human health and well-being. As such, we need to re-think the way we produce, consume, and dispose of products. According to ISPRA (Istituto Superiore per la Protezione e la Ricerca Ambientale), Italian packaging waste can be collected either as a mono-material or as a multi-material stream, when two or more material fractions are collected together in a single bin. Several dissimilar multi-material schemes continue to exist in Italy, for example, paper and plastic; paper, plastic, aluminium, and ferrous metals; plastic, aluminium, and ferrous metals; glass, paper, aluminium, and ferrous metals; glass, aluminium, and ferrous metals; and paper, glass, plastic, and aluminium [46]. When a multi-material collection system is in place, the packaging waste streams require a preliminary step of separation between the different materials [59]. Further, the main problems are the glass recycling logistics after collection and an efficient management for bar and restaurant collection. 
Therefore, an overall improvement of the Italian waste management framework can seriously contribute to better outcomes. On one hand, both a better and greater spread collection of glass by dedicated bells and an increase of glass recycling rates through technological innovations capable of minimizing disposed waste must be implemented. For instance, different typologies of municipal waste, among which are glass bottles, have been analyzed considering the feasibility of their reuse and upcycling for assembling building envelope structures able not only to respect the thermal transmittance limits imposed by the European regulatory framework, but also to reduce the waste amount to be treated thanks to local reuse [60]. On the other hand, it is essential to promote better information to citizens about the need to avoid conferring other materials (ceramics, porcelain, crystal, light bulbs, etc.) in glass collection, but particularly essential is the optimization of municipal waste management, especially in areas of Italy where non-biodegradable materials occupy large parts of landfills.

\section{Conclusions}

Cullet represents an essential resource for the European container glass industry. Particularly since the most important container glass-producing countries, such as Italy, can play a pivotal role in exploring energy and material efficiency options, as well as carbon-emission reduction, to resolve threats posed by environmental degradation and global warming. This is a consequence of cullet's major systematic impact on melting energy for any melting technology or furnace size.

The paper highlights that cullet use in the Italian context is limited by external factors, particularly regarding the availability of suitable cutlet in some southern regions. The need to improve state-of-the-art Italian glass collection schemes, especially in areas with quantitative or qualitative inefficiencies, is a fundamental challenge to face in future decades. At the same time, innovations in glass re-processing technology, including colour sorting, are essential in improving current results.

A more eco-efficient implementation of integrated packaging glass recycling management, in which both waste glass that can be closed-loop recycled and contaminated waste glass or low-quality glass (e.g., glass powder) not suitable for container glass production, becomes urgent for Italy in order to meet the new European targets. This represents a key example of a multi-output reprocessed approach, promoting synergies in an industrial symbiotic landscape and driving value creation: fundamental principles underpinning a circular economy.

This study confirms that significant results can be achieved by energy-intensive industries, such as container glass manufacturing, relative to enhancing environmental profile, adopting sustainability as a business imperative, and implementing models that create common value and drive systematic change towards a functional circular economy.

The study outlines the following directives:

- Developing collection and recycling waste glass systems in Italy must find solutions suited to local realities, with the support of appropriate and targeted financial measures, while sharing knowledge on the management of container glass waste.

- Identifying good practices in the selective collection and closed-loop recycling of glass packaging waste from Municipal Solid Waste (MSW) across European and Italian regional and local authorities.

- Implementing different collection schemes (kerbside, bottle banks, deposit schemes, and other types of schemes), including sectorial differences for glass collection (commercial, household) and/or colour-separate glass collection versus mixed glass collection.

- Increasing the quality and efficiency of the glass recycling value chain through efficient collection and quality recycling, investing in Italian cullet treatment centers where used glass is sorted, freed of impurities, and crushed to make clean cullet ready to be transformed into new glass.

- $\quad$ Evaluating the performance of the different glass collection schemes. 
- $\quad$ Promoting synergic partnerships and networks of all stakeholders to embed programs and synchronize business and environmental goals.

- Re-engineering the waste management supply chain, and also optimizing the paths of reverse collection and logistics, focusing on 'multiple' closed-loop frameworks by stakeholder partnerships and networks at various levels, and sharing knowledge and skills.

- Raising awareness amongst households and other targets through communication and education campaigns.

This research, however, presents some limitations, as it is based on secondary data collected from the reports of European and Italian representative organizations in the container glass industry and waste management; therefore, all limitations suffered by secondary data are applicable to this study.

Further research could examine the performance of other important container glass producers in Europe, such as Germany or France, or other emerging producer countries worldwide to compare their industrial approaches regarding glass waste management, use of cullet, and energy sources utilized. Unfortunately, most of these data are currently not made available by the leading organizations that operate in the container glass sector at the European and global levels. Therefore, the availability of homogeneous statistical data obtained through harmonized measurement systems for cullet collection, sorting, and recycling will help to intensify research related to the economic, environmental, and social sustainability of the European glass container industry.

Acknowledgments: This research did not receive any specific grant from funding agencies in the public, commercial, or not-for-profit sectors.

Author Contributions: The work illustrated in this paper was coordinated by Ornella Malandrino. Mario Testa designed the research and wrote the paper. Stefania Supino provided advice and maintained relationships with institutions and experts. Maria Rosaria Sessa gathered information and synthetized data. Daniela Sica improved the language. All of the authors contributed in equal parts to the fulfilment of the paper.

Conflicts of Interest: The authors declare no conflicts of interest.

\section{References}

1. McLellan, G.W.; Shand, E.B. Glass Engineering Handbook; McGraw-Hill: New York, NY, USA, 1984.

2. Schmitz, A.; Kamiński, J.; Scalet, B.M.; Soria, A. Energy consumption and $\mathrm{CO}_{2}$ emissions of the European glass industry. Energy Policy 2011, 39, 142-155. [CrossRef]

3. Scalet, B.M.; Garcia Muñoz, M.; Sissa, A.Q.; Roudier, S.; Delgado Sancho, L. Best Available Techniques (BAT) Reference Document for the Manufacture of Glass, Industrial Emissions Directive 2010/75/EU (Integrated Pollution Prevention and Control); JRC Reference Report; European Union: Luxembourg, 2013; Available online: http:/ / eippcb.jrc.ec.europa.eu/reference/BREF/GLS_Adopted_03_2012.pdf (accessed on 22 March 2017).

4. IEA. Tracking Industrial Energy Efficiency and $\mathrm{CO}_{2}$ Emissions. 2007. Available online: https:/ /www.iea. org/publications/freepublications/publication/tracking_emissions.pdf (accessed on 11 April 2017).

5. Miketa, A. Analysis of energy intensity developments in manufacturing sectors in industrialized and developing countries. Energy Policy 2001, 29, 769-775. [CrossRef]

6. Supino, S.; Malandrino, O.; Testa, M.; Sica, D. Sustainability in the EU cement industry: the Italian and German experiences. J. Clean. Prod. 2016, 112, 430-442. [CrossRef]

7. EIA. Annual Energy Outlook with Projections to 2040; DOE/EIA-0383; U.S. Energy Information Administration, Office of Energy Analysis, U.S. Department of Energy: Washington, DC, USA, 2016. Available online: https: / / www.eia.gov / outlooks/aeo/pdf/0383(2016).pdf (accessed on 31 March 2017).

8. Glass Alliance Europe. Industries. 2012. Available online: http://www.glassallianceeurope.eu/en/ industries (accessed on 31 March 2017).

9. Glass Alliance Europe. Common Challenges. 2012. Available online: http:/ /www.glassallianceeurope.eu/ en/common-challenges (accessed on 31 March 2017).

10. Lieder, M.; Rashid, A. Towards circular economy implementation: A comprehensive review in context of manufacturing industry. J. Clean. Prod. 2016, 115, 36-51. [CrossRef] 
11. Waite, S.; Cox, P.; Tudor, T. Strategies for local authorities to achieve the EU $202050 \%$ recycling, reuse and composting target: A case study of England. Resour. Conserv. Recycl. 2015, 105, 18-28. [CrossRef]

12. European Commission. Establishing Criteria Determining When Glass Cullet Ceases to Be Waste under Directive 2008/98/EC of the European Parliament and of the Council, Commission Regulation (EU) No 1179/2012, 10 December 2012. Available online: http:/ / eur-lex.europa.eu/legal-content/EN/TXT/ PDF/?uri=CELEX:32012R1179 (accessed on 31 March 2017).

13. Vieitez, E.R.; Eder, P.; Villanueva, A.; Saveyn, H. End-of-Waste Criteria for Glass Cullet: Technical Proposals, JRC Scientific and Technical Reports; European Union: Luxembourg, 2011. Available online: http:/ /ftp.jrc.es/ EURdoc/JRC68281.pdf (accessed on 30 March 2017).

14. European Commission. Report from the Commission to the European Parliament, the Council, the European Economic and Social Committee and the Committee of the Regions on the Implementation of the Circular Economy Action Plan COM (2017) 33 Final, 26 January 2017; European Commission: Brussels, Belgium, 2017.

15. Kirk, O. Encyclopedia of Chemical Technology. Fluorine Compounds, Organic to Gold and Gold Compounds, 3rd ed.; Wiley: New York, NY, USA, 1980; Volume 11.

16. Dan, K.; Ward, L. The History of Glass; Orbis: London, UK, 1984.

17. Rasmussen, S.C. Origin of Glass: Myth and Known History. In How Glass Changed the World; SpringerBriefs in History of Chemistry; Springer: Berlin/Heidelberg, Germany, 2012.

18. Jacobs, M.B. Review of How Glass Changed the World: The History and Chemistry of Glass from Antiquity to the 13th Century. J. Chem. Educ. 2015, 406-407. [CrossRef]

19. Encyclopedia Britannica. Geaorge Ravenscroft. Available online: www.britannica.com/biography/GeorgeRavenscroft (accessed on 1 April 2017).

20. Glass Alliance Europe. EU Glass Production. 2012. Available online: http:/ / www.glassallianceeurope.eu/ images/cont/production-evolution-2015_file.pdf (accessed on 1 April 2017).

21. Glass Alliance Europe. Production Evolution within Sectors. 2012. Available online: http://www. glassallianceeurope.eu/images/cont/production-evolution-2015-by-sectors_file.pdf (accessed on 1 April 2017).

22. Industrial Efficiency Technology Database. Glass. 2017. Available online: http://ietd.iipnetwork.org/ content/glass (accessed on 1 April 2017).

23. Worrell, E.; Galitsky, C.; Masanet, E.; Graus, W. Energy Efficiency Improvement and Cost Saving Opportunities for the Glass Industry; An ENERGY STAR ${ }^{\circledR}$ Guide for Energy and Plant Managers; Energy Analysis Department Environmental Energy Technologies Division, Ernest Orlando Lawrence Berkeley National Laboratory, University of California: Berkeley, CA, USA, 2008. Available online: https://www.energystar.gov/ia/ business/industry/Glass-Guide.pdf (accessed on 8 May 2017).

24. Ecoprog. Glass Factories under the Industrial Emissions Directive. Sites, Competition and Investment Potentials in Europe. 2014. Available online: http://www.ecoprog.com/fileadmin/user_upload/ leseproben/ext_market_report_glass_factories_in_europe_IED_ecoprog.pdf (accessed on 11 April 2017).

25. Supino, S. Evoluzione dei consumi energetici nell'industria del vetro in Italia. Riv. Stn. Sper. Vetro. 2001, 3, 9-16.

26. European Economic and Social Committee. Opinion of the European Economic and Social Committee on an Industrial Policy for the European Glass Sector. CCMI/127 Glass Industry, 22 April 2015. Available online: http:/ / www.eesc.europa.eu/?i=portal.en.ccmi-opinions.32821 (accessed on 16 March 2017).

27. Researchandmarkets. APAC Glass Containers Market-by Countries and Vendors-Market Trends and Forecasts (2014-2020). 2017. Available online: http:/ / www.researchandmarkets.com/reports/3515904/ apac-glass-containers-market-by-countries-and (accessed on 8 May 2017).

28. FEVE. EU Container Glass Production Growth Shows Industry Resilience. 2015. Available online: http:/ / feve.org/wp-content/uploads/2016/04/EU-container-glass-production-growth-shows-industryresilience.pdf (accessed on 8 May 2017).

29. FEVE. Glass Packaging Industry Making the EU Circular Economy Real. 2015. Available online: http:/ / www.nvc.nl/userfiles/files/FEVE_Press_Release.pdf (accessed on 1 April 2017).

30. FEVE. Recycling. Why Glass Always Has a Happy $\mathrm{CO}_{2}$ Ending. 2010. Available online: http://feve.org/wpcontent/uploads/2016/04/FEVE-brochure-Recycling-Why-glass-always-has-a-happy-CO2-ending-.pdf (accessed on 16 March 2017).

31. FERVER. Glass Recycling: Years of Improvement, Glassman Europe. 2015. Available online: http:/ / www. glassmanevents.com/europe/content-images/misc/FERVER.pdf (accessed on 16 March 2017). 
32. Federico, L.M.; Chidiac, S.E. Waste glass as a supplementary cementitious material in concrete-Critical review of treatment methods. Cem. Concr. Compos. 2009, 31, 606-610. [CrossRef]

33. Idir, R.; Cyr, M.; Tagnit-Hamou, A. Pozzolanic properties of fine and coarse color-mixed glass cullet. Cem. Concr. Compos. 2011, 33, 19-29. [CrossRef]

34. Ruth, M.; Dell'Anno, P. An industrial ecology of the US glass industry. Resour. Policy 1997, 23, 109-124. [CrossRef]

35. Wartman, J.; Grubb, D.G.; Nasim, A.S.M. Select engineering characteristics of crushed glass. J. Mater. Civ. Eng. 2004, 16, 526-539. [CrossRef]

36. Ahmad, F.; Mujah, D.; Hazarika, H.; Safari, A. Assessing the potential reuse of recycled glass fibre in problematic soil applications. J. Clean. Prod. 2012, 35, 102-107. [CrossRef]

37. Bignozzi, M.C.; Saccani, A.; Barbieri, L.; Lancellotti, I. Glass waste as supplementary cementing materials: The effects of glass chemical composition. Cem. Concr. Compos. 2015, 55, 45-52. [CrossRef]

38. Jani, Y.; Hogland, W. Waste glass in the production of cement and concrete-A review. J. Environ. Chem. Eng. 2014, 2, 1767-1775. [CrossRef]

39. Arulrajah, A.; Disfani, M.M.; Maghoolpilehrood, F.; Horpibulsuk, S.; Udonchai, A.; Imteaz, M.; Du, Y.J. Engineering and environmental properties of foamed recycled glass as a lightweight engineering material. J. Clean. Prod. 2015, 94, 369-375. [CrossRef]

40. Blengini, G.A.; Busto, M.; Fantoni, M.; Fino, D. Eco-efficient waste glass recycling: Integrated waste management and green product development through LCA. Waste Manag. 2012, 32, 1000-1008. [CrossRef] [PubMed]

41. Ellen MacArthur Foundation. The Circular economy and the Promise of Glass in Concrete. Available online: https: / www.ellenmacarthurfoundation.org/assets/downloads/circular-economy/The-CircularEconomy-and-the-Promise-of-Glass-in-Concrete.pdf (accessed on 22 March 2017).

42. Tiozzo, S.; Favaro, N. Permanent Materials in the Framework of the Circular Economy Concept: Review of Existing Literature and Definitions, and Classification of Glass as a Permanent Material. Report 136480. 2016. Available online: http:/ / feve.org/wp-content/uploads/2016/09/SSV-Report-on-Glass-as-PermanentMaterial.pdf (accessed on 16 March 2017).

43. FEVE. Glass Recycling Hits 73\% in the EU. Best Performing Bottle to Bottle Closed Loop Recycling System. 2015. Available online: http:/ / feve.org/wp-content/uploads/2016/04/Press-Release-EU.pdf (accessed on 1 April 2017).

44. Hsieh, Y.C.; Lin, K.Y.; Lu, C.; Rong, K. Governing a Sustainable Business Ecosystem in Taiwan's Circular Economy: The Story of Spring Pool Glass. Sustainability 2017, 9, 1068. [CrossRef]

45. Eurostat. Municipal Waste Generation and Treatment, by Type of Treatment Method. 2016. Available online: http: / / ec.europa.eu/ eurostat/tgm/refreshTableAction.do?tab=table\&plugin=1\&pcode=tsdpc240\& language=en (accessed on 8 May 2017).

46. ISPRA. Rapporto Rifiuti Urbani. 2016. Available online: http://www.isprambiente.gov.it/files/ pubblicazioni/rapporti/RapportoRifiutiUrbani_Ed.2016_n.251_Vers.Integrale_ErrataCorrige.pdf (accessed on 28 March 2017).

47. Rigamonti, L.; Ferreira, S.; Grosso, M.; Marques, R.C. Economic-financial analysis of the Italian packaging waste management system from a local authority's perspective. J. Clean. Prod. 2015, 87, 533-541. [CrossRef]

48. Rigamonti, L.; Grosso, M.; Sunseri, M.C. Influence of assumptions about selection and recycling efficiencies on the LCA of in of integrated waste management systems. Int. J. Life Cycle Assess. 2009, 14, 411-419. [CrossRef]

49. Rigamonti, L.; Grosso, M.; Giugliano, M. Life cycle assessment of sub-units composing a MSW management system. J. Clean. Prod. 2010, 18, 1652-1662. [CrossRef]

50. ASSOVETRO. Relazione alla Assemblea Generale delle Aziende Associate; ASSOVETRO: Roma, Italy, 2015.

51. ASSOVETRO. Relazione alla Assemblea Generale delle Aziende Associate; ASSOVETRO: Roma, Italy, 2016.

52. CONAI. Programma Generale di Prevenzione e Gestione degli Imballaggi e dei Rifiuti di Imballaggi. 2015. Available online: http:/ /www.conai.org/wp-content/uploads/2016/07/PGP_CONAI_2016.pdf (accessed on 16 March 2017).

53. CoReVe. Piano Specifico di Prevenzione 2016, Risultati di Raccolta e Riciclo 2015. 2016. Available online: https:/ / www.coreve.it/pdfdownload/risorse_documenti_download_pdf_90.pdf (accessed on 28 March 2017). 
54. Fondazione per lo Sviluppo Sostenibile. Dossier. Il Riciclo del Vetro e i Nuovi Obiettivi Europei per la Circular Economy. 2016. Available online: http://www.reteambiente.it/repository/normativa/23897.pdf (accessed on 16 March 2017).

55. Canalenergia, Raccolta vetro. Co.Re.Ve: 3Mln di euro al Sud per chi fa Squadra. 2017. Available online: https:/ / www.canaleenergia.com/archivio-rubriche/42-smart-city/5667-raccolta-vetro-coreve-3mln-di-euro-al-sud-per-chi-fa-squadra.html (accessed on 1 April 2017).

56. CoReVe. Piano Specifico di Prevenzione 2015, Risultati di Raccolta e Riciclo 2014. Available online: https: //www.coreve.it/pdfdownload/risorse_documenti_download_pdf_434084139.pdf (accessed on 28 March 2017).

57. CoReVe. CoReVe Scommette sul Sud per Incrementare la Raccolta del Vetro. 2017. Available online: https: / / www.coreve.it/showPage.php?template=news\&id=111 (accessed on 8 May 2017).

58. Delle Selve, M. Research Favours Separated Collection for Effective Recycling, Glass International. 2012. Available online: http:/ /www.glass-international.com/contentimages/features/FEVE_00_GI_0909.pdf (accessed on 28 March 2017).

59. Giugliano, M.; Cernuschi, S.; Grosso, M.; Rigamonti, L. Material and energy recovery in integrated waste management system. An evaluation based on life cycle assessment. Waste Manag. 2011, 31, 2092-2101. [CrossRef] [PubMed]

60. Pennacchia, E.; Tiberi, M.; Carbonara, E.; Garcia, D.A.; Cumo, F. Reuse and Upcycling of Municipal Waste for ZEB Envelope Design in European Urban Areas. Sustainability 2016, 8, 610. [CrossRef]

(C) 2017 by the authors. Licensee MDPI, Basel, Switzerland. This article is an open access article distributed under the terms and conditions of the Creative Commons Attribution (CC BY) license (http://creativecommons.org/licenses/by/4.0/). 